\title{
Shipping Routes and Spice Trade in Southeast Sulawesi During the 17th and 18th Century
}

\author{
Susanto Zuhdi \\ Department of History, Faculty of Humanities, Universitas Indonesia
}

\begin{abstract}
This paper discusses the dynamics of sea voyage and trade formed in the network of Southeast Sulawesi waters in the 17th and 18th century. Buton was chosen as a port that played the role in that network. Southeast Sulawesi as the concept of region will be positioned in the eastern and southern part of Sulawesi network, and other parts of the Nation. In addition to the strategic location connecting Makassar to North Maluku and Central Maluku, also spices as the commodities transported through this line, Buton has its own trade commodities, such as slaves, and iron tools (knives, machetes). Although it is not in large in numbers, cloves from Buton were also the target of VOC. As a collecting center port, Buton plays a role in the network of "feeder point" ports such as Raha and

Received:

20 August 2018

Revised:

22 September 2018

Accepted:

8 November 2018

Corresponding author: susanto_zuhdi@yahoo.com Tukangbesi Islands (now Wakatobi), with the entrepot, Makassar. The changes after Makassar fell into VOC's hands has made Buton contributing more as a supplier. Although Buton was an ally of VOC, marked by a contract signed in 1613, but in some respects there was resistance, both openly as Buton War in 1755 and rebel against the ban on growing cloves (extirpation) and illegal trade (sluijkhandel). Literature review and tracking down of primary sources in the form of archives and oral tradition are important steps for further study.
\end{abstract}

Keywords: Shipping Routes; Spice Trade; Southeast Sulawesi.

\section{Introduction}

Before discussing this topic further, notes should be considered related to the title requested by the committee. There are two things that need to be explained its meaning, that is "spices" and "Southeast Sulawesi". Spices are trading goods originating from the eastern world to Indonesia which are highly sought-after and are the driving force of Europeans exploring the world massively and striving hard to obtain them. In a broad sense, the spices include approximately 188 types of plants from India to Maluku. ${ }^{1}$ Due to the spices trade activity, the spices network was formed. It seems that the "spice routes" were more promoted than the former term, the "silk routes". Silk is one of the commodities in Asian trade route with China as the producer. The term "silk" in world trade is not only seen as a good or material, but it means "suavity" that may represent cultural expressions in the sense of international interaction. In the 1990s, UNESCO launched to raise the values of "silk road" in many scientific activities through discussions and sea voyage, as well as festival with the theme "Silk Road". Directorate General of Culture of the Ministry of Education and Culture of the Republic of Indonesia in the 1990s conducted discussion and traveling activities by setting some ports to be the discussion theme in the context of the Silk Road. The ports of the Silk Road are: Sunda Kelapa, Cirebon, Ternate, Demak, Tuban.

${ }^{1}$ Jack Turner, Sejarah Rempah Dari Eksotisme sampai Imperialisme (Depok, Penerbit Komunitas Bambu: $2011)$, xxiv-xxv. 
In contrast to the silk road, the spice route has its own story. If the silk road is already accepted concept, the 'spice route' struggling to be acknowledged remains a discourse. In this paper 'spice route' is used loosely to show that it is the biggest commodity in term of volume. Therefore, the discussion is within the scope of trade with spices commodities taking the sea routes across the Nation.

First, the "spices" trade through sea routes in the archipelago refers to commodities such as nutmeg, mace (fuli), cloves, which are generally originated from the Maluku Islands. In fact, there are other commodities such as pepper produced from Sumatra and Kalimantan. Secondly, regarding the term Southeast Sulawesi in the sense of provincial government area which applies in the current concept. In this context, the definition needs to be expanded and associated to other areas of Central Sulawesi, North Sulawesi, and even Maluku. As a consequence of that perspective, Southeast Sulawesi should be put into a wider maritime network, in the sense that it is not only related to the eastern coast of Sulawesi, but to the east and southwest of the archipelago, to Java, or even to the Malacca Strait. While the path which leads to the north, to North Sulawesi, will reach the Philippines, and then to the Sea of China. Currently, Southeast Sulawesi is an area of government within the scope of the provincial administration established since 1960. This region was administratively listed under the Provinces of South and Southeast Sulawesi (Sulselra) with its center in Makassar. Southeast Sulawesi province in historical perspective covers almost the majority of the former territory of the Sultanate of Buton (14001960). In the perspective of Dutch Colonial Government, Buton even (read: Baubau) was once the capital of afdeling Buton-Laiwui .

This paper is to explore the maritime network by placing Buton in the 'spice route' voyage in Indonesian Archipelago. The name Buton (Butun) has long been known in the national history, at least as revealed in Warnana Village, or better known as Nagarakartagama by Mpu Prapanca (1365) read as: "Ikang saka sanusa nusa makasar butun banggawi // kunir galiyau mwangi salaya sumba solor muar // muwah tikang-i wandhamambwanathawa malako wanin // ri serani timur makadiningangeka nusa tutur", meaning "Islands like Makasar, Butun-Banggawi // Kunir, Galiyan, and Selayar, Sumba, Solor, Muar // also Wandan, Ambon, or Maluku, Wanin // Seram, Timor and other islands nearby". ${ }^{2}$

The spice route actually does not literally mean that the traded goods are "spices" only, but also other commodities such as rice, diamonds, sandalwood. There has been a mutual trade or exchange of commodities across the nation and wider region. Many spices are produced in Maluku, such as clovesa nutmeg, and also pepper, especially on the west coast of Sumatra and Banten. The commodities coming from abroad brought by Indians and Chinese including cloth, silk, and porcelain were exchanged with domestic commodities.

By tracing back, the name of places written in Nagarakartagama, this paper seeks to describe sailing and trading activities and analyzes them with a framework for port category: entrepot, collecting center, and feeder point. ${ }^{3}$ By using the framework, the paper is intended to identify the impact of the fall of Sombaopu, Makassar Port into the hands of the VOC / Dutch on the sailing and trading in Southeast Sulawesi. Meanwhile, by examining the relationship between ports by showing Baubau as a "collecting center" port in Southeast Sulawesi, it is expected to explain the shipping patterns established. It is also important to understand the patterns of sea-oriented coastal societies formation. The elements that build shipping networks by making the sea as a system integrating the islands into a wider network. Historian A.B. Lapian

${ }^{2}$ I Ketut Riana, Kakawin Desa Warnana uthawi Nagarakrtagama Masa Keemasan Majapahit (Jakarta, Penerbit Buku Kompas: 2009), 102.

${ }^{3}$ Sau Heng Leong, “Collecting Centres, Feeder oints and Entrepot in the Malay Peninsula, c. 1000 B.C.-A.D. 1400" in Kathiritambi-Wells, J. \& John Villiers, The Southeast Asian Port and Polity Rise and Demise (Singapore, Singapore University Press: 1990), 17-38. 
proposed the study of maritime history primarily on the theory of sea system to examine the process which is relevant tothe context of "Indonesian- ness" now. ${ }^{4}$

Other considerations that encourage this study are the sea areas that are still neglected, including the east coast of East Sulawesi. Velthoen (1997) has initiated the study by focusing analysis on political and trade violence that goes beyond the reach of central power. In the 19th century, the Dutch colonial made a change as the government influence was increasingly felt by the people of the islands. Entering the 20th century, the system of colonial government was greatly seen as the spatial arrangement with the realization of "pax neerlandica" was proclaimed. Not all regions have an important position, in the sense of concern and interest, from Batavia perspective. In that context, there are areas considered as "peripheries" and attract Velthoen's attention to study these regions with a "state-formation" framework. Regarding these matter, the question is formulated as: "Is Indonesia continuing the colonial policy that ignores the periphery areas such as the sea region of East Sulawesi?"

\section{Routes or Ports First?}

There is an adage in maritime history related to a classical question of whether the sea routes causing the establishment of harbor or the port that creates the sea routes. The answer or explanation of this question is basically the same, that is the establishment of maritime network. In the sea network pattern, there is a relationship between ports with their respective characteristics and the significance of the roles of port category. With the sailing based on a particular network pattern running, the next classic question is whether: "trade follows the flag or the flag follows the trade? The notion of "trade follows the flag" means that all commercial activity takes place after the power or political aspects are enforced. While the meaning of "flag follows the trade" represents a metaphor that the power enforcement is preceded by trade activity.

The explanation or answer to the question whether "route" or "harbor" comes first or vice versa, may be easier to grasp by using the common sense: the two processes go hand in hand. While the explanation of the "flag" or "trade" requires more concrete evidence and indeed should be provided since it is a concept that needs to be accounted for. The former deals with the concept of economy because it refers to trading activity, while the latter deals with politics. This concept uses the metaphor of "flag" which is a symbol showing the meaning of "politics". So in principle, the metaphor represents a close relationship between "economy" and "politics". It should also be noted that the religious factor for Portuguese arrival in this country might be greater than that of Dutch merchants (Luhulima, $\mathrm{tt}$ ). This LIPI researcher explains the difference between the Dutch who ignored the religious matter in its eastern trade and the expansion of Portuguese which was driven by (1) the crusade against the Muslims, (2) the thirst of gold from the coast of Guinea (3) the search for John the Baptist, (4) effort to find spices. ${ }^{5}$ The voyage activities indeed are for economic and political purposes which also involves other aspects of life whether it is intentional or not. The voyages and trades made by various nations allow for a cultural encounter which spawned various aspects of life. It is because the interactions between communities or nations in the ports also allows the ideas and thoughts sharing, even establishing the relationship of marriage and cultural contacts which produce

${ }^{4}$ A. B. Lapian, A.B. Orang Laut, Bajak Laut, Raja Laut: Studi Kawasan Laut Sulawesi, Disertasi UGM, 1997. See also "Bacan and the early history of North Maluku" in Leontine E. Visser ed. Halmahera and Beyond Social Science Research in the Moluccas (Leiden, KITLV Press: 1992).

${ }^{5}$ C. P. F. Luhulima, "Motif-motif Ekspansi Nederland Dalam Abad Keenambelas", Terbitan Tidak Berkala No.II/14 Lembaga Penelitian Kebudayaan Nasional, Lembaga Ilmu Pengetahuan Indonesia (LIPI), Djakarta 9, without year. 
In the study of port cities in Asia, particularly in the period of 1600-1800, the dynamics of cultural interaction between immigrants and the local community emerged and gave birth to the new forms and types of 'civilization'. ${ }^{6}$ By analyzing the comparison of the shape and characteristics of each port, the book of anthologies with various of topics proposes six aspects. The first comparison can be made about the location, ownership and architectural aspects of the ports and VOC's office/company buildings in the port cities. Secondly, regarding the communication between Europeans and local people at the harbor. Third, the comparison of how trade is run by various trading companies of different nations. Fourth, the aspects that can be compared are those related to the official population and what happened to them involving the local people. Fifth, about the relationship between male and female. Especially between European men and local women. What is the social class of their children? Last but not least, the sixth aspect is the history of everyday life at the port cities. Such interactions happen in reallife situation is interesting to be observed as an outcome of cultural interaction. ${ }^{7}$ Of course, not all of the above comparisons can be applied in any context and places. However, Haneda's ideas are challenging to be considered in the study of port cities in Indonesia.

Referring back to the first adage of voyage and port relationships in this paper, it is not to answer which one precedes or causes and its effects. The two factors are likely to affect each other. Sailing in the waters of eastern Sulawesi as the focus of this paper is revealed from the oldest local manuscript, Nagarakartagama (1635). Butun-Banggawi shows two names of territories connected by sea networks since long time ago. The relationship was established at least since the 14th century as the first written manuscript in the archipelago called it.

\section{Southeast Asia Sea and Maritime Zone Network}

In the history of the archipelagic region which later became the territory of the present state of Indonesia, in fact it is a part formed from cross-island sea network in the archipelago itself and more broadly. Indonesia, known as the archipelago state and long-known as "the land beneath the wind" is within the sea routes links of East Asia and West Asia. The voyages and trades run by Chinese to India led "the land beneath the wind" to grow rapidly, especially in the western region. The Strait of Malacca is a strategic position that determines the maritime activities of various nations. As a consequence, the western region of Indonesia was developed first than the eastern region. In its development, the eastern region primarily became the driving force of trade history with Europe most sought-after commodity: spices.

Before the arrival of European in the 16th century, sailing traffic in the archipelago was long happened with the establishment of zones or maritime areas. Kenneth Hall in a link to the voyage at that time shows the maritime zones in the pre-modern maritime network in Southeast Asia. First, the zone covering the northern part of the Malay Peninsula and the southern coast of Vietnam. This was the first attempt and convenience of East-West trade in the last millennia BC period. During this time, Southeast Asia was seen by foreign sailors as an intermediate region between the rich regions, that is India and China. The agency that plays a role in this region was Malay-Polynesian sailors who made a far sea journey westward to the coast of Africa to China in the east. Second, the second and third periods were marked by the emergence of the Java Sea area. The Java Sea network is mainly associated with ups and downs of trading goods such as gaharu wood, sandalwood, and spices such as cloves from Nusa Tenggara and Maluku Islands, eastern coast of Kalimantan, Java, and the southern coast of Sumatra. The development of the

\footnotetext{
${ }^{6}$ Masashi Haneda, Asian Port Cities, 1600-1800: Local and Foreign Cultural Interactions (Singapore, National Universityof Singapore: 2009).

${ }^{7}$ Haneda, Asian Port Cities, 8-10.
} 
trade center of this age is noted as Ko Ying, located near the Sunda Strait, an internationally strategic port. The Malay seaman connected Ko Ying to Funan. Third, the Southeast Asian trading area is the Melaka Strait, with its center in the southern coast of Sumatra. This place quickly became the "focal point" of Malay trade in the western area of Borneo, Java, as well as the eastern islands, as the Malay Peninsula with its hinterland, and supported by the Chao Praya and Irrawady river system. O.W. Wolters refers the southern part of Sumatra as a "favored coast" that adds value to the commercial development, markets of Sumatra forest products and trading goods in Java Sea, and also utilization of Malay vessels and their crew connecting the domestic networks with international routes. Penetration of Chinese seaman who came from the north to south in the Sulu Sea to obtain commodities from the spice islands gave birth to the fourth trading area. Chinese merchants built trade headquarters in the Philippines during this period. In a network to distribute imports and to collect forest products that are a commodity of interest to Chinese merchants, it is an intensive and extensive network for local traders in the network that raises the change for Filipinos. Furthermore, Southeast Asia's fifth trading area is in the Bay of Bengal during the post-Sriwijaya era. Trade activities in the Bay of Bengal covers the mainland political system and the former Sriwijaya territory that is the northern part of the Malay Peninsula and western Sumatra which established trade relationship with southern parts of India and Sri Lanka. ${ }^{8}$

After the fall of Sriwijaya, at least since the 13th century, Southeast Asia international trade was again held by Southeast Asia. Until that time, the five commercial maritime regions lived a prosperous life and free economic network. It represents the greatest empire of Majapahit, located in East Java. The Javanese rulers provided facilities for the spice trade in Java Sea in order to control several ports in the Straits of Malacca in the same way as Srivijaya ruled. Malacca was also emerged, when China was dominated by the Ming Dynasty and absent due to pirate disruption in 1430. The prosperity of Malacca was sustained by the Javanese trade, especially the spice trade of the east. The fall of Malacca was later marked by the emergence of Aceh, Johor, and Jambi.

The long process of sailing in Southeast Asia shows territorial units or zones, as illustrated by Hall: The first maritime area covers the western to eastern part of the Bay of Bengal, starting from the coast of Coromandel in southern India and Srilanka, including Burma (Myanmar), Upper Malay Peninsula, and the western coast of Sumatra. Secondly, the commercial area, that is Melaka Strait is the main port in the 15th century, which was previous oscillated between Thai and Javanese kingdom. The third area is the territory including the eastern coast of the Upper Malay Peninsula, Thailand and the Lower Coast of Vietnam, as well as the border region of Thailand Gulf. The Thailand kingdom developed in the first half of the 14th century, located centrally in the Chao Praya Valley due to factors of relationship with outside expansion that had an effect and aroused conflict with Malacca. Fourth, the Sulu Sea region includes the western coast of Luzon, Mindoro, Cebu, and Mindanao in the Philippines, as well as the Brunei on the northern coast of Borneo. All of these areas with their respective levels, facilitate the trade between China and the spice islands, a route that is a continuation of the Chinese-built base in Philippines in the 11th and 12th centuries. From this spice islands, nutmeg, mace, clove, sandalwood, parrot, cenderawasih flow through the Sulu Sea to China and Thailand northward as well as westward of: Java and Malacca. Finally, the fifth, the Java Sea network which included Southeast Asia in the 15th century, consisting of Nusa Tenggara, Maluku, Banda, Timor, Western Kalimantan, Java and the southern coast of Sumatra. ${ }^{9}$

${ }^{8}$ Kenneth Hall, Maritime Trade and State Development in Earley Southeast Asia (Honolulu: University of Hawaii Press: 1985), 20-25.

${ }^{9}$ Hall, Maritime Trade, 225-227. 


\section{Buton in Domestic Network}

The strategic roles of Buton in maritime networks, especially to the Maluku Islands, was strongly proved by the presence of Portuguese in the archipelago. After occupying Malacca in 1511, the Portuguese immediately expanded its trade to Maluku. Tome Pires logbook to the King of Portugal, indicates his prowess in sailing the route to the spice islands, saying:

“... to serve Your Majesty - people will find out that to reach Maluku, it does not have to pass the Java coast, but through Singapore. From Singapore, they sailed to Borneo, then to Buton Island (Butum) and finally to Maluku. The men who has sailed to Maluku agree that this route is a good and fast path, especially during the rainy season.

[...] [...] Kalimantan route is suitable for us since we do not have to stop by at each port from one country to another, we do not sell goods here and there to make money from every place ... ". ${ }^{10}$

Sailing through Buton was considered beneficial and fast. Therefore, the Portuguese chose this route. Comparing with the route through Java, it is considered by Portuguese merchants as a long-lasting route because they have to stop at some ports, therefore it is unprofitable. Journey through Java is called a waste of time. It is even said that the Kalimantan-Buton route was the best.

The road to the east, towards the spice production sites, became more open to the Portuguese after they took over Malacca. In addition to using traditional sea route of local sailors, the Portuguese also traveled through the northern coast of Borneo. Consequently, it is popularized by Malay merchants through the west coast of Sumatra, the Sunda Strait, and the north coast of Java, and eastward. In the development of this voyage, the trading activities was increasingly crowded, especially in making Makassar as a major port in the eastern part of the archipelago.

The fall of Malay trading center in Malacca has made the crowd switched to Aceh, Jambi, Johor and Java ports. Johor which attempted standing equally high as Malacca, began to show trading activity in the mid-16th century, while Aceh which is larger than Johor was able to develop its trade relationship to West Asia. Jambi as the source of pepper producers that the Portuguese need, as well as the Java ports: Jepara, Demak, and Gresik which in principle continued in trade relationship with the Portuguese Malacca. However, the economic interests of these cities has conflicts with the Portuguese settlements. Beside the three port cities, Portuguese trade relationship also took place in the western part of Java with the development of the sultanate of Banten.

As Roelofsz (2016) suggests, the greatest influence of Portuguese on the indigenous economy took place in the spice islands, but it should not be said that indigenous trade was completely destroyed. After the fall of Malacca, there has been a change related to the voyage. Sailing to west coast of Sumatra shows crowded activity. Direct trade with east and west then has been running again. Initially, many traders, especially Gujarati Muslim merchants, avoided the Melaka Christian center. They began to find their way to Java ports through the Sunda Strait. ${ }^{11}$

\footnotetext{
${ }^{10}$ Tome Pires, Suma Oriental Perjalanan Dari Laut Merah ke Cina \& Buku Fransisco Rodrigues, translated (Yogyakarta, Penerbit Ombak: 2014), 304-305.

${ }^{11}$ Meilink Roelofsz, M.A.P. Persaingan Eropa \& Asia di Nusantara Sejarah Perniagaan 1500-1630, translated (Depok, Komunitas Bambu: 2016), 107.
} 
Banda is the free trade center of domestic spices, that is fruit and nutmeg, or cloves from Maluku, Ambon, and Seram. After the Banda population vanished due to the massacre of VOC, Ambonese traders were meaningless without the help of Javanese merchants. Using a small boat with capacity of 16 to 24 tons, Ambonese merchants obtained knives and machetes from the Banggai Islands, Buton and Selayar. ${ }^{12}$ The network to Java that includes Buton appears in traders' activity from Gresik by using west winds to the east, i.e. to the Sunda Kecil Islands (Nusa Tenggara) and spice islands, Buton, Buru, Mindanao, and Kai and Aru Islands. ${ }^{13}$ Sailing to the eastern part of the Indonesian archipelago from the ports of Java Gresik, Jaratan and Sedayu; with ships of 20 tons using a monsoon. When the east monsoon blows they sail to the south of Malacca, while during the west monsoon the ships sail to the Sunda Kecil Islands (Nusa Tenggara) and the Spice Islands (Maluku), Buton, Buru, Mindanao and Kai Islands and Aru. ${ }^{14}$

Java relationship with the eastern region through Gresik was not only due to trade but also because of the spread of religion and the establishment of the Java community in several places. Bacan has a close family relationship with Gresik, even the king is a descendant of Gresik. If present-day perspectives are used, Buton is a sultanate that covers most of the province of Southeast Sulawesi. Before Islam entered and developed, Buton was an area under the influence of Majapahit. In local history records, the third king named Tuarade had been to Majapahit to study the government administrative which then practiced in the Kingdom of Buton. Buton' close relationship with Majapahit is like a relic which is considered to be an evidence as a tomb of Gajah Mada followers of 40 people in Majapahit Village in Batauga, Buton rests. The change of the sultanate mane occurred when the fifth king of Buton converted to Islam. There are several version regarding the entry of Islam to Buton, but two of them are prominent. First, Islam was brought by Baabullah, the Sultan of Ternate, while the second said Islam had first entered Buton before the presence of Ternate. ${ }^{15}$

In 1615, Tuban could still be referred to as ruling the sea activities. More specifically the role of Jepara, Gresik, and Surabaya ports as "Account of some Wars in the Indies" as quoted from Schrieke:

"From these places above mentioned, namely Grise, Jaratan, and Sedayu, great commerce is carried on at sea on all parts of the Indies, for they have a multitude of ships. In those places there can be a thousand and more boats of twenty, fifty, to two hundred tons, with which they steadly carry on their trade, and it must be taken into account that one never sees half the ships at home, for they sail with the moonsoons. With the eastern monsoon they go to the Straits of Malacca, Sumatra, Palembang, Borneo, Patani, Siam, and a hundred other places too many to tell. With the western monsoon they go to Bali, Bantam, Bima, Solor, Timor, Alor, Salayar, Buton, Buru, Banggai, Mindanao, the Moluccas, Ambon, and Banda, which has now been taken from them. Also to the islands of Kai, Aru, Ceram, and other places to many to relate where they do business in bartering goods and make at least two or three hundred per cent. profit before they return home... Wherever they go, namely while they wait for the other monsoon to go back home again, they pull their junks or ships onto the beach, the which they are able to do very skillfully. First they make little huts of the sort of booths at fairs, where they bring all their merchandise and display it, so that there are Indies fairs..." ${ }^{16}$

\footnotetext{
${ }^{12}$ Roelofzsz, Persaingan Eropa, 214.

${ }^{13}$ Roelofsz, Persaingan Eropa, 266.

${ }^{14}$ Roelofsz, Persaingan Eropa, 266.

${ }^{15}$ Susanto Zuhdi, Sejarah Buton yang Terabaikan Labu Rope Labu Wana (Jakarta, Rajawali Grafindo: 2010),

${ }^{16}$ Schrieke, Indonesian Sociological Studies (The Hague, W. van Hoeve: 1955), 20.
} 107. 
From the explanation above, Buton is clearly in a vast network, marked by Buton as one of the links in the route, from the Malacca Straits north to Patani, Siam, Mindanao, to the east, Banda, Aru, and other places.

\section{Buton: Maritime Kingdom between Ternate and Gowa}

Talking about the roles of Buton in the sea and trading networks in East Sulawesi region, it cannot be separated from the governmental structure of a maritime kingdom. The name "Butun" is mentioned in the order with Banggai in Nagarakartagama (1365), as interpreted by A.B. Lapian, is not a merely coincidence. The addressing indicates a relationship, in which means a fairly intensive voyage. The establishment of the Buton Kingdom is appealing to be observed since in its local tradition, it is called Mia Patamiana (literally "The Four Man"), consisting of Sipanjonga, Sitanamajo, Sijawangkati, and Simalui originating from Johor. Does the local source come from unrecorded information and only remembered and then considered a myth, yet the meaning tells that life in the archipelago is often related to travel stories or migration? An assumption can be proposed, for example when Siam invaded Tumasik (Singapore) in the 14th century, or the Portuguese conquest of Malacca in 1511 which resulted in the movement of people seeking for a new life.

Within two years of the fall of Malacca, the Portuguese had arrived in the North Maluku Islands. A Portuguese man named Jacob records a living oral tradition in Bacan about the myth of Bikusigara. The myth is about a man named Bikusigara who traveled around Bacan Island and stopped when he heard a voice from the bushes. He found four large snake eggs. Bikusigara was asked to keep the four eggs well because of the eggs would hatch great people who control the countries of Maluku and the east. So, the eggs made these four figures: A King of Bacan, a King of Papua, a King Butung-Banggawi, and a woman married to King Loloda. ${ }^{17}$

The entry of Islam is a new myth in contributing legitimacy to the establishment of the Sultanate of Buton. Once a wonderer from Arabia received orders from Prophet Muhammad PBUH to sail towards the sunrise and he arrived on an island. The man wearing the robe then let took it off for a moment. The people wonder who the man wearing the robe was. There sits a bird chirping "butuni, butuni" nearby. It is said that the sound of the bird was name after Buton, coined from the word "butuni". While the cloaked man was regarded as the "waliulloh" or the messenger of God. From the name that is said the name of the Sultanate of Wolio also originated, or become one of the districts in Baubau City today. In addition to the name, a myth also told about the establishment of the royal center by logging and preparing land called as welia. In Wolio language, welia means cutting down the trees or shrubs for a land ready to be used for establishing of a community of life.

Islam provides the basis for the formation of the government structure of the Buton Sultanate as described below. By applying the teachings of "seven dignity" which initially developed in Aceh, the Sultanate of Buton is widely known as an Islamic archipelago sultanate. The conception of Buton as the structure of a real royal power had just started in the 19th century when the Dutch colonial government began to affirm the territory that included into its hegemony. Buton territory was depicted through maps and descriptions of archipelagic regions and oceans made by the Dutch, as described by Ligtvoet (1878).

${ }^{17}$ A. B. Lapian, Garuda Indonesia a Journey of Dedication45th of Garuda Indonesia (Jakarta, Garuda Indonesia: 1994), 13. 
Buton has a port around Baubau now, a port that is considered strategic because it is in the route from west to east towards the spice islands. As noted by J.P. Coen that Baubau Port is a good harbor for boat to stop and for various purposes such as docking and anchor. ${ }^{18}$

The VOC's interest in Buton is actually higher because of its strategic location, seen according to the route from Makassar to Ternate. It is in this critical route that Gowa has long held the hegemony seeking to prevent or even avoid the VOC in order to gain maximum profit from spice trade to North Maluku. To Buton, Gowa is a threat or even an enemy that continuously attacks its sovereignty. Therefore, it was such a "tit for tat" when the interests of the VOC and Buton both to face Gowa. It was easy to understand then that a friendship contract was created between them in an agreement between Sultan Dayanu Ihsanudin with the title La Elangi, and VOC Officer named Appolonius Schotte in 1613. The dynamics of the alliance between Buton and the VOC did not always go smoothly in the following years. Sultan Buton did not subject to the contract completely. Sultan Himayatudin (1752-1755) for example, a man who dared to violate the advance contracts with VOC and even challenged it to spark the outbreak of Buton War. Fort Wolio was attacked by VOC troops in February 1755 resulting hundreds of Sapati and Kapitalao killed. In the collective memory of the Buton natives, that time is commemorate as Zamani Kaheruna Walanda (The Age of Dutch Riot). ${ }^{19}$

With the fall of Makassar into the hands of the VOC, after the great war taking down Sultan Hasanuddin throne, it does not mean that the VOC can fully took control over the sea route and trade in the region. Knaap and Sutherland (2004) conclude that upon Bungaya Treaty was signed in 1667, VOC rulers in Rotterdam fortress were not intended to control the voyages of private maritime vessels and trade in and around Makassar. Its main purpose was to issue a travel pass system used by the VOC port authorities to ensure the safety of navigation in that areas and prevent threats to the VOC's trade monopoly in producing spices and textile entry from India. In fact, VOC was unable to oversee the sailing and trade in the Java Sea, the Makassar Straits, the Flores Sea and the wider waters. VOC tried to handle the commercial activity by making use of diplomacy with local rulers and or by patrol boats. In the South Sulawesi Peninsula, the powerful allies often questioned the VOC right to oversee ship voyages and trade, while different regional ports of Makassar maintained their relationship with the outside world.

Competition of the rulers were also aware of the political benefits through the trade. According to Knaap and Sutherland, further research is required, especially on non-VOC trade patterns, i.e. trade showing the relationship between Sulawesi and the country traders from India. ${ }^{20}$

The illustration of the growing private trade as recorded by the port authorities in Makassar between the 1760s and 1770s can be seen from the influx of large quantities of liquor from Batavia, as well as rice and cotton from Sumbawa, sea cucumber from various coastal areas around the Flores Sea. Sea cucumber is re-exported to China. In 1746 sea cucumber was exported directly to Amoy (Canton) and indirectly through Batavia. Briefly, the character of Makassar Port is as an importer of sea cucumber and exporter of liquor (Knaap and Sutherland 2004: 169).

Meanwhile, the eastern Sulawesi network appears to be outside the "crowded" route, but that does not mean none activity is important to observe. Velthoen has embarked on an in-depth study of this region in relation to areas far from the central power and thus tends to appear "small" power conflict in trade competition. There is a certain character in the history of the region due to political and economic factors as a result of the conflict and war between Ternate,

${ }^{18}$ Zuhdi, Sejarah Buton, 63.

${ }^{19}$ Zuhdi, Sejarah Buton. See also S. Zuhdi \& Muslimin R. Effendy, Perang Buton vs Kompeni-Belanda 17521776, Mengenang Kepahlawanan La Karambau (Depok, Penerbit Komunitas Bambu: 2014).

${ }^{20}$ Gerrit Knaap dan Heather Sutherland, Monsoon Traders: Ships, Skippers and Commodities in EighteenthCentury Makassar (Leiden, KITLV: 2004), 167. 
Gowa, Bone and VOC in fighting over power and economic influence. Although the latter aspect is not as influential as other regions, especially for the VOC. ${ }^{21}$ To understand better the dynamics of trade in this region in the 18th century, we can see it through the figure of private vessels (local traders) movement in the Port of Makassar, as follows.

\section{Figure 1. The number of ship movements in the port of Makassar in the $18^{\text {th }}$ Century}

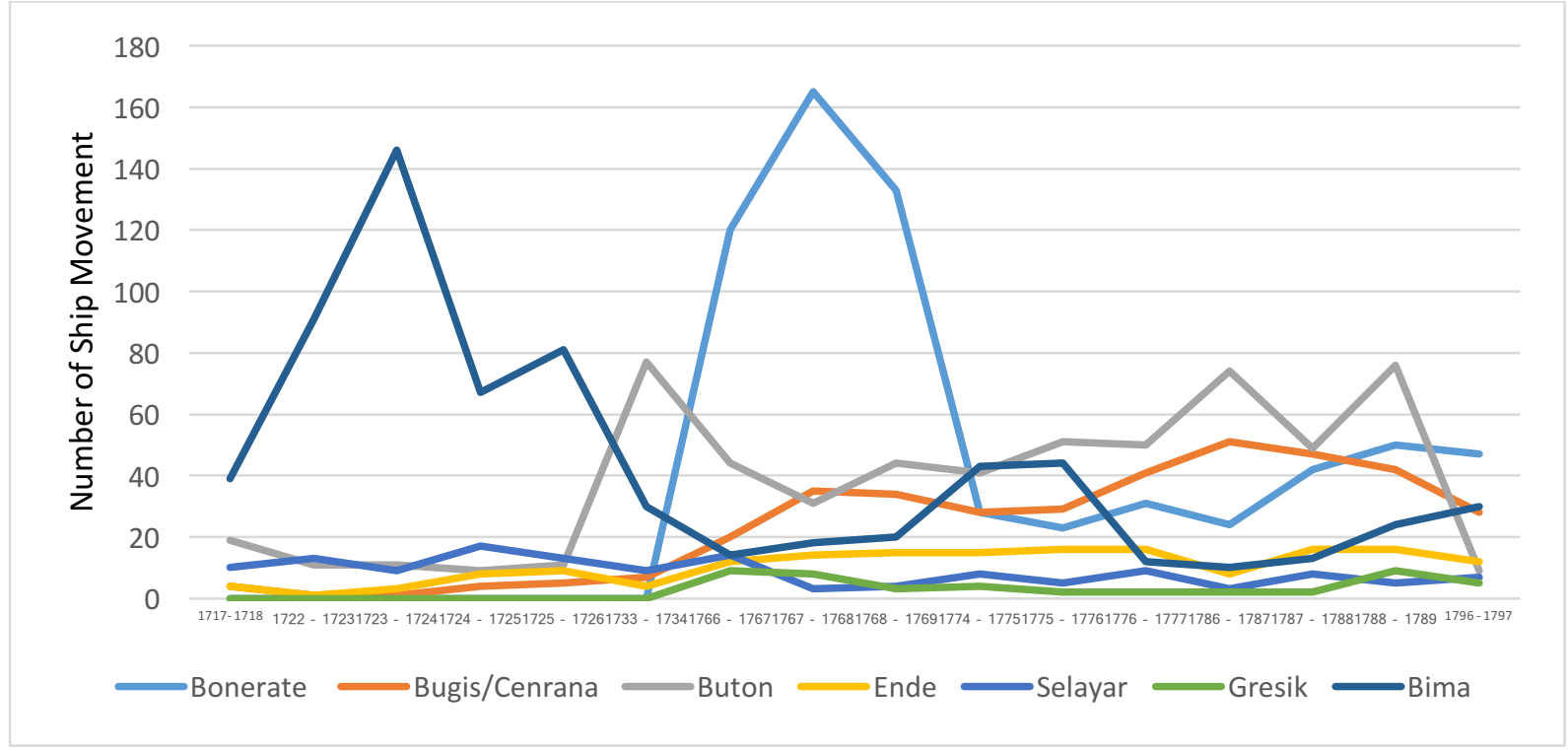

Source: Knaap and Sutherland, 2004: 197.

From the figure, it can be seen how the local traders in the 18th century conducted their trade activities, and competing simultaneously. The Buton merchants, in the Figure 2, is in the third place following Bonerate and Bima in the first and second place. Furthermore, the Figure 2 illustrates the volume of trading traffic in Makassar during the 18th century.

Figure 2. The number of ship movements in the port of Makassar in the $18^{\text {th }}$ Century

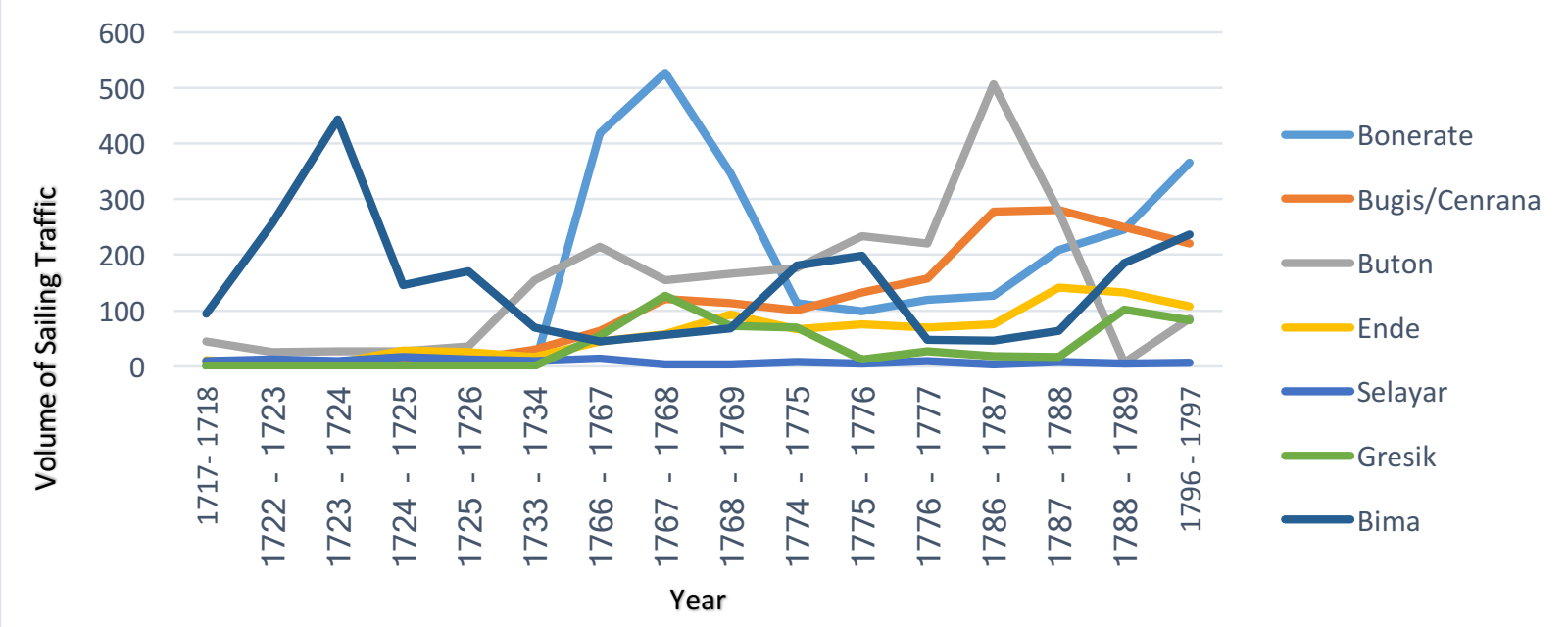

Source: Knaap and Sutherland, 2004.

${ }^{21}$ Esther Velthoen, 'Wanderers, Robbers and Bad Folk': The Politics of Violence, Protection and Trade in Eastern Sulawesi 1750-1850", in Anthony Reid, ed. The Last Stand of Asian Autonomies Responses to Modernity in the Diverse States of Southeast Asia and Korea, 1750-1900 (Houndmills, Basingstoke, Hampshire and London: MacMillan Press Ltd, 1997). 
The table above shows a more detail information on how the dynamics of private sail in Makassar. Even in 1777-1787, the traffic volume of Buton merchant in Makassar reached its peak, exceeding Bima and slightly below Bonerate. It shows the intense competition between merchants, which also contributed to the ups and downs of their sailing volume in Makassar. Therefore, by looking at the port of Makassar as a sample case, it can be said that in the 18th century, local traders from the eastern Indonesia continued to trade and sail intensely in the midst of a massive VOC monopoly.

\section{Internal Dynamics of Buton: Response to VOC Hegemony}

Although the quality and volume of clove products from the islands in Buton was not as good and large, but VOC has an interest in it. This is seen from the reports of company officials in overseeing the clove planting on the islands of Buton. The contract between Buton-VOC in 1766 contains peace following the conflict and even open war as the effect of the sinking of Rust en Werk vessel. The war, led by Sultan Himayatudin, popularly known as La Karambau, in 1755, scratched deep wounds for the people of Buton. Regarding those issue, Abd. Ganiyu Kenepulu Bula wrote a kabanti (poet) entitled Ajonga Inda Malusa.

As a result of the contract, VOC strictly oversaw planting and trading in Buton. However, frequent attempts were taken to penetrate the control. It can be seen from VOC complaint over the practice of "illegal trading" (sluijkhandel). With this fact, it can be said that the contract or agreement between the VOC and the Buton only applied on paper. The agreement between the palace and VOC officials does not necessarily mean that it should be implemented on lower level. Not to mention the implementation of the overseeing of spices and commercial activities of the Buton native. Therefore, a fleet of the two contracting parties is needed to oversee a vast territory covering many islands in Buton. One of the most difficult areas to be overseen by VOC fleet in Buton region is Tukang Besi Islands. VOC complained about the difficulty of carrying out extirpation, in addition to trading of nutmeg, pepper, lena, and opium. These commodities were prohibited by VOCs for trading in areas that have been declared as part of their control.

In an official report received by VOC, there is no "smuggling" practice. However, in spite of the facts, the sultan must be held accountable for the agreement he has made. VOC has an eye for the sultan's attitude who often "let" the practice did by Butonese. It seems that the VOC knew the sultan did not prevent the locals in Lengkesi Islands, Kaputa, Kalisusu, Siompu, and Kadatuang as berthing boats containing the illegal commodities.

News from reports received by VOC is as follows:

"Niet tegenstaande de visiteur in vorige jaaren ons telken berigt hebben, van geen sluijkhandelaaren aldaar gevonden, ter negotie werden geadmiteerd. So als wij daartegen aan de andere zijde niet zonder de uijterse ontsligting hebben gezien, hoe den koning van Bouton C.I. in weer wie van het bezwooren contract tusschen de generaale Nederlandsche Oost Indische Compagnie en het Boutonse hoof subsistereende, UE in allen deelen onder frivole pretenten gecontradiceerd, en nit (met) allen belet hebben de visitatie der voorst sluijkhandel drijvende vaartuigen, maar teffens ook die van de negorij Borangasse, de Eijlanden s'Mattheus, Kapoeta, Kalisoesoe, Tjatja, Siompo, en Kadatuang, en waar door ons zoo veel te meer reedent tot verdenking gegeven is, dat die districtten mogelijk niet ontleedig van specerij boomen zijn." 22

Translation:

${ }^{22}$ Zuhdi, Sejarah Buton, 236. 
"We [VOC] received a report from an investigator that in the past years, there was no smuggling. On the other hand, it can be seen how the Buton chief who signed the contract with the VOC, only partially fulfilled it and vice versa, and did not allow the investigators to block smuggling, also in Burangasse State, Mattheus Islands, Kaputa, Kalisusu, Caca, Siompu and Kadatuang, where there are so many reasons and thought for us that the districts might be working on something, planting spice trees".

The sovereignness of the sultan or Buton ruler to cling to the contract with the VOC is still questionable as VOC continues to warn of the "disobedience" of the Butonese people. VOC surveillance in sailing and trading continues to be conducetd by issuing travel letter or a pass in their territory so that Buton party will obey it. ${ }^{23}$ However, no matter how hard VOC tried to prevent illegal trading, judging from its interest, it still continued. This is evident from the VOC letter to Sultan Alimuddin La Masalumu (m. 1788-1791):

"Shah and as we say that many trade people do not bring fitting and he did not stop at Buton as well he went to other places like in Tombuku and in Banggai and Sula and other places, then that's where he returned with prohibition, then he did not tell King Buton". ${ }^{24}$

The relationship between Buton and Bungku do not limited to the trade aspect only. There is a power relation between the two. The relationship between Buton and Tombuku is interesting to be asked for the question of what kind of relationship pattern is going on between them. In the memory of the Buton people as recorded by Ajonga Inda Malusa, the work of Abd. Ganiyu, Kenepulu Bula, it is revealed:

$\begin{array}{ll}\text { Mapangurapina motingarapina lipu } & \text { Who wants to subdue the country } \\ \text { Moneyatina bemo humbubina kota } & \text { Who intend to attack the fort } \\ \text { Siyambau gowa atoluwu otobungku } & \text { Like Gowa, Luwu and Tobungku } \\ \text { Tee malingu saro simbapuyana } & \text { And so-called attackers }\end{array}$

From this local source, it appears that Buton and Tobungku relationships are in an equal position. In such circumstances it allows competition, so that it can be understood in which Buton considers Tobungku as a threat to defeat it, and vice versa. ${ }^{25}$ Viewed from Tobungku, also through its local sources, there is a close relationship. Tobungku Kingdom still retains the memory of the role of a woman from Buton who became the queen of Bungku. There are interesting kinship relationships to be raised when talking about Buton and Bungku. According to local sources, the second consort of king Bungku is the descendant of Wa Kaa Kaa namely Waode Petiy with the title "Sope Bangka Binoti". Shee brought her three brothers, La Huleko, La Hupanda, and La Huuledan, a woman. She also invited four groups from Tangkeno, ToKoroni, To-Kambofa, and To-Moahi tribes. ${ }^{26}$

Observing the trade aspect relating to Buton, it is interesting to say that it does not quite fit the commitment of the Buton authorities to comply with the contracts made with the VOC. Sergeant Kumpeni reported that it can be seen that Buton had trade relations with Banjarmasin, Johor, and other regions for long. The small merchant voyage made by local people to Buton

\footnotetext{
${ }^{23}$ Zuhdi, Sejarah Buton, 237.

${ }^{24}$ Zuhdi, Sejarah Buton.

${ }^{25}$ Mahid, Syakir, Haliadi Sadi, W. Darsono, Sejarah Kerajaan Bungku (Yogyakarta: Penerbit Ombak), 253.

${ }^{26}$ Mahid, et al., 2012: 251-2.
} 
from Cenrana Bay carrying rice and salt can penetrate the blockade without VOC recommendation. ${ }^{27}$

Buton trading network is even broader if it is linked to Bugis. Because of them, Buton was able to connect to the Southeast Asia. In the local source of Buton, kabanti Ajonga Inda Malusa, also revealed about the role of Bugis in the Buton trade.
Kaapaaka sabaraka podaga
For all trades
Mopadagana iyumalata siroo
Trading on our river there
Bari bariya batuyana Bone
All of them is the people of Bone
Saide mpuu lipu mosagaana
Very few from other countries

The image that Buton trading is mostly attributed to slaves, is not really true. At least in its development, especially in the late decade of the 18th century, sea cucumber is a feature commodity from Buton. Table 1 shows the Buton trade in Makassar Port according by the numbers.

Table 1. Imported Sea Cucumber in Makassar Port in pikul

\begin{tabular}{|c|c|c|c|c|c|}
\hline & $1722-23$ & $1733-34$ & $1766-67$ & $177-77$ & $1786-87$ \\
\hline Ambon & - & 15 & - & - & - \\
\hline Banda & - & 68.5 & - & - & 250 \\
\hline Barru & - & 20 & - & - & - \\
\hline Belitung & 15 & - & - & - & - \\
\hline Bima & - & - & - & 69 & - \\
\hline Bonerate & - & - & 478 & 291 & 141 \\
\hline Bugis & - & - & 200 & 587 & 485 \\
\hline Buton & 10 & 276 & 631 & 1071 & 1077 \\
\hline Cenrana & - & 30 & - & - & - \\
\hline \multicolumn{6}{|l|}{ Bone } \\
\hline Komodo & - & - & 40 & 55 & - \\
\hline Manggarai & - & 29 & - & - & - \\
\hline Pasir & - & 10 & - & - & - \\
\hline Pulau Laut & - & 8 & - & - & - \\
\hline Selayar & - & - & 11 & - & - \\
\hline Sumbawa & - & - & 50 & 493 & 622 \\
\hline Ternate & - & - & - & - & 10 \\
\hline Total & 25 & 456.5 & 1410 & 2566 & 2625 \\
\hline
\end{tabular}

From the data listed above, more than six years Buton became a commodity supplier of sea cucumber to the Port of Makassar. The highest number of sea cucumber imports to Makassar is from Buton, compared to the supply from other ports.

\section{Conclusion}

The most sought-after commodity in trade outside Europe, which is in the eastern world is the spice. The spices of the Moluccas Islands that have changed the history of European trade spectacularly around the 15th century. Cloves, nutmeg, and mace are few of the most precious types of spice. The sea route from the western archipelago to Maluku traditionally through the waters of Southeast Sulawesi, where Buton became a central role in connecting with other areas. Buton or Butun has been revealed in Nagarakartagama (1365), a state in the sphere of influence of Majapahit. Buton has Baubau harbor, which abounded by boats from various regions, became

${ }^{27}$ Zuhdi, Sejarah Buton, 238. 
an integral part of the Archipelago Sea network, long before the arrival of Europeans. Buton is increasingly important as it becomes the main sea route to Maluku Islands, the main spiceproducing hub. In regional dynamics, Buton was a political entity that has its own powers amidst the expansion of Gowa and Ternate. The arrival of Europeans in the spice trade world through Buton adds to the complexity of power and economic relations between the various interests. Theories about the marine system A.B. Lapian (1992\&1994) explaining the process of integration of the islands through the Archipelago Sea network, shows the role of Buton especially in the waters of Southeast Sulawesi. More important to say, the development of the spice route has placed Buton in a reciprocal role as one of the maritime axis of Indonesia.

\section{References}

Turner, Jack. Sejarah Rempah Dari Eksotisme sampai Imperialisme. Depok: Penerbit Komunitas Bambu, 2011.

Riana, I Ketut. Kakawin Desa Warnana uthawi Nagarakrtagama Masa Keemasan Majapahit. Jakarta: Penerbit Buku Kompas, 2009.

Sau Heng, Leong. "Collecting Centres, Feeder oints and Entrepot in the Malay Peninsula, c. 1000 B.C.-A.D. 1400" in J. Kathiritambi-Wells \& John Villiers. The Southeast Asian Port and Polity Rise and Demise. Singapore: NUS Press, 1990.

Lapian, A.B. Orang Laut, Bajak Laut, Raja Laut: Studi Kawasan Laut Sulawesi. Yogyakarta: Unpublished Ph.D Thesis Universitas Gadjah Mada.

Lapian, A.B. "Bacan and the early history of North Maluku" in Leontine E. Visser ed. Halmahera and Beyond Social Science Research in the Moluccas, Leiden, KITLV Press: 1992.

Luhulima, C.P.F. "Motif-motif Ekspansi Nederland Dalam Abad Keenambelas". Terbitan Tak Berkala No.II/14. Lembaga Research Kebudayaan Nasional, Lembaga Ilmu Pengetahuan Indonesia (LIPI) Djakarta, 9.

Haneda, Masashi. Asian Port Cities, 1600-1800: Local and Foreign Cultural Interactions. Singapore, National Universityof Singapore, 2009.

Hall, Kenneth. Maritime Trade and State Development in Earley Southeast Asia, Honolulu: University of Hawaii Press, 1985.

Pires, Tome. Suma Oriental Perjalanan Dari Laut Merah ke Cina \& Buku Fransisco Rodrigues. Yogyakarta: Penerbit Ombak, 2014.

Meilink-Roelofsz, M.A.P. Asian Trade and European Influence in the Indonesian Archipelago Between 1500 and About 1630. The Hague: Martinus Nijhoff, 1962.

Zuhdi, Susanto. Sejarah Buton Yang Terabaikan Labu Rope Labu Wana, Jakarta: Rajawali Grafindo, 2010.

Schrieke, B. Indonesian Sociological Studies. The Hague: W. van Hoeve, 1955.

Lapian, A. B. Garuda Indonesia a Journey of Dedication45th of Garuda Indonesia. Jakarta: Garuda Indonesia, 1994.

Zuhdi, S., Effendy, Muslimin R. Perang Buton vs Kompeni-Belanda 1752-1776. Mengenang Kepahlawanan La Karambau. Depok. Penerbit Komunitas Bambu, 2014.

Knaap, Gerrit and Sutherland, Heather. Monsoon Traders: Ships, Skippers and Commodities in Eighteenth-Century. Makassar. Leiden: KITLV, 2004.

Velthoen, Esther. 'Wanderers, Robbers and Bad Folk': The Politics of Violence, Protection and Trade in Eastern Sulawesi 1750-1850, in Reid, Anthony ed. The Last Stand of Asian Autonomies Responses to Modernity in the Diverse States of Southeast Asia and Korea, 1750-1900. Houndmills, Basingstoke, Hampshire and London: MacMillan Press Ltd., 1997. Mahid, Syakir, Sadi, H., Darsono, W. Sejarah Kerajaan Bungku. Yogyakarta: Penerbit Ombak, 2012. 